\title{
Booklet sebagai Suplemen Bahan Ajar pada Materi Kingdom Animalia untuk Peserta Didik Kelas X SMA/MA
}

\author{
Putri Novianti ${ }^{*}$, S. Syamsurizal ${ }^{2}$ \\ 1,2 Jurusan Biologi, Universitas Negeri Padang, Padang, Indonesia
}

\section{A R T I C LE I N F O}

Article history:

Received August 05, 2021

Revised August 08, 2021

Accepted September 18, 2021

Available online December 25, 2021

Kata Kunci:

Booklet, Suplemen Bahan Ajar, Biologi

Keywords:

Booklet, Teaching Material Supplements, Biology

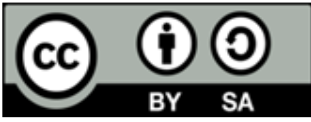

This is an open access article under the CC BY-SA license.

Copyright (C) 2021 by Author. Published by Universitas Pendidikan Ganesha.

\begin{abstract}
A B S T R A K
Booklet merupakan media pembelajaran berukuran kecil yang penyajiannya jauh lebih singkat daripada buku dengan satu topik materi, sehingga memudahkan peserta didik untuk dibawa kemana-mana. Berdasarkan hasil observasi didapatkan bahwa sebanyak $82 \%$ peserta didik kesulitan memahami materi Kingdom Animalia serta diketahui bahwa selama proses pembelajaran sudah digunakan media pembelajaran berupa buku paket dan LKPD. Namun, peserta didik masih membutuhkan sumber bahan ajar tambahan pada materi Kingdom Animalia dengan sebanyak $82 \%$ peserta didik setuju dalam pengembangan booklet dengan harapan dapat meningkatkan minat belajar peserta didik pada materi kingdom animalia. Penelitian ini bertujuan untuk menguji validitas booklet pada materi Kingdom Animalia kelas X SMA/MA yang telah dikembangkan dengan menggunakan tiga tahapan dari model pengembangan 4D (define, design, develop dan disseminate) yang dilakukan sampai tahap develop, yaitu uji validitas kepada dosen biologi dan guru biologi. Metode pengumpulan data yang digunakan adalah instrumen berupa angket. Teknik analisis yang digunakan adalah teknik analisis statistik deksriptif. Hasil rata-rata nilai validasi booklet adalah $97.66 \%$ dengan kategori sangat valid, dengan uraian dari 4 aspek penilaian yaitu 94,80\% pada aspek kelayakan isi, $100 \%$ pada aspek kebahasaan, 95,83\% pada aspek penyajian, dan $100 \%$ pada aspek kegrafikan. Kesimpulan uji validitas booklet pada materi Kingdom Animalia memnuhi kategori sangat valid dan dapat diujicobakan pada penelitian selanjutnya.
\end{abstract}

\section{A BS TRAK}

Booklets are small learning media whose presentation is much shorter than books with one material topic, making it easier for students to carry everywhere. Based on the results of observations, it was found that as many as $82 \%$ of students had difficulties in understanding the Kingdom Animalia material and it was known that during the learning process, learning media in the form of textbooks and worksheets were used. However, students still need additional sources of teaching materials on Kingdom Animalia material with as many as $82 \%$ of students agreeing to develop booklets in the hope of increasing students' learning interest in Kingdom Animalia material. This study aims to test the validity of the booklet on the Kingdom Animalia class X SMA/MA material that has been developed, using three stages from the $4 D$ development model (define, design, develop and disseminate) which is carried out to the develop stage, namely validity testing for biology lecturers and teachers. biology. The data collection method used is an instrument in the form of a questionnaire. The analytical technique used is descriptive statistical analysis technique. The average result of the booklet validation value is $97.66 \%$ with a very valid category, with a description of 4 assessment aspects, namely $94.80 \%$ in the aspect of content feasibility, $100 \%$ in the linguistic aspect, $95.83 \%$ in the presentation aspect, $100 \%$ in the graphic aspect. . The conclusion of the booklet validity test on Kingdom Animalia material meets the very valid category and can be tested for further research.

\section{PENDAHULUAN}

Media pembelajaran adalah perantara berupa sumber belajar yang digunakan guru dan peserta didik yang menunjang kegiatan belajar (Intika, 2018). Media pembelajaran efektif dalam meningkatkan motivasi peserta didik dan menstimulasi peserta didik mengingat materi (Adiko, 2019; Putra \& Milenia, 
2021; Rejeki et al., 2020; Sya'bania et al., 2020). Media dikembangkan semenarik mungkin agar menarik perhatian didik mempelajarinya serta harus disesuaikan dengan kompetensi yang akan dicapai peserta didik. Media pembelajaran dirancang dengan memerhatikan karakteristik peserta didik agar materi pembelajaran dapat dipahami oleh peserta didik dengan baik. Untuk itu, guru dituntut kreatif dalam mengembangkan media pembelajaran. Berdasarkan observasi yang dilakukan di SMAS Pertiwi 2 Padang didapatkan bahwa media pembelajaran yang digunakan dalam proses pembelajaran biologi berupa buku paket dan LKPD. Penggunaan buku paket dan LKPD masih menyulitkan peserta didik karena topik pembahasannya sangat luas dan memiliki lebih dari satu topik materi, sehingga tampak buku paket dan LKPD memiliki ukuran yang tebal dan berat.

Salah satu topik materi biologi yang dipelajari peserta didik kelas X adalah materi kingdom Animalia. Berdasarkan angket yang disebarkan kepada 21 peserta didik didapatkan bahwa 82\% peserta didik kesulitan dalam memahami materi Kingdom Animalia. Hal ini disebabkan oleh materi terlalu banyak dan terdapat istilah-istilah yang membingungkan, sehingga peserta didik membutuhkan sumber bahan ajar tambahan pada materi kingdom animalia. Media pembelajaran yang dapat menjadi sumber bahan ajar tambahan digunakan peserta didik berupa booklet. Booklet merupakan media pembelajaran berukuran kecil yang berisi tulisan dengan ilustrasi yang menarik perhatian peserta didik (Aini \& Habibi, 2020; Nisa et al., 2021). Penyajian isi materi pada booklet lebih singkat daripada buku. Booklet dengan bentuknya yang kecil dan ringan memudahkan peserta didik untuk membawanya kemana-mana. Booklet berisikan informasi-informasi penting, jelas, dan mudah dimengerti oleh peserta. Booklet dapat menjadi media pendamping untuk proses pembelajaran sehingga meningkatkan efektivitas pembelajaran peserta didik (Pralisaputri, 2016; Rahmatih et al., 2017; Yudistira et al., 2021). Booklet ini dapat menambah referensi selain buku paket dan LKPD yang digunakan, sehingga booklet dapat digunakan sebagai suplemen bahan ajar.

Suplemen bahan ajar merupakan tambahan bahan yang sudah ada sebagai bahan pengayaan untuk peserta didik untuk meningkakan memotivasi peserta didik (Rahmatih et al., 2017; Yudistira et al., 2021). Suplemen bahan ajar digunakan guru dalam proses pembelajaran, sehingga dapat melengkapi bahan ajar yang telah ada. Dengan adanya suplemen bahan ajar membantu proses pembelajaran menjadi efektif dan peserta didik dapat memahami materi dengan baik. Berdasarkan observasi didapatkan, sebanyak $82 \%$ peserta didik setuju dalam pengembangan booklet pada materi kingdom animalia sebagai suplemen bahan ajar kelas. Penelitian ini didukung oleh penelitian (Yusuf et al., 2019) yang menghasilkan booklet sejarah perang Lasem yang layak dan efektif digunakan dalam pembelajaran sejarah lokal dengan meningkatkan hasil belajar peserta didik. Selanjutnya, penelitian (Sari, 2019) mendapatkan hasil bahwa booklet lebih efektif dibandingkan media leaflet dalam meningkatkan pengetahuan remaja tentang dampak kehamilan remaja di SMA Swasta Pertiwi Kota Jambi. Oleh karena itu, booklet sebagai suplemen bahan ajar dengan penyajian materi yang lebih sederhana dan terfokus pada satu topik materi dapat meningkatkan minat peserta didik. Berdasarkan latar belakang yang telah diuraikan, penelitian ini bertujuan untuk menganalisis validitas booklet pada materi kingdom animalia kelas pada peserta didik kelas X. Hasil penelitian ini dapat digunakan dalam pengembangan suplemen bahan ajar berupa booklet pada penelitian selanjutnya.

\section{METODE}

Penelitian ini merupakan penelitian pengembangan (Research and Development). Model yang digunakan mengadaptasi dari model 4D yang dikembangkan oleh Thiagarajan. Model 4D terdiri dari 4 tahapan yaitu define (pendefinisian), design (perancangan), develop (pengembangan) dan disseminate (penyebaran). Penelitian ini dilaksanakan sampai tahap develop (pengembangan) terutama tahap validasi yang dilakukan oleh 2 orang dosen biologi dan 1 orang guru biologi. Instrumen yang digunakan adalah lembar validasi yang memuat aspek kelayakan isi, penyajian, kebahasaan, dan kegrafikan. Teknik analisis yang digunakan analisis deksriptif dengan beberapa langkah, pertama, memberikan skor jawaban dengan skala Likert yang dimodifikasi dari (Rosyidah et al., 2019) dengan kriteria sebagai berikut: SS (sangat setuju $)=\operatorname{bobot} 4, \mathrm{~S}($ setuju $)=\operatorname{bobot} 3$, TS $($ tidak setuju $)=\operatorname{bobot} 2$, STS $($ sangat tidak setuju) $=$ bobot 1 . Kedua, menentukan skor tertinggi. Ketiga, Menentukan jumlah skor dari setiap indikator. Menentukan skor yang diperoleh dengan menjumlahkan skor dari validator. Keempat, menentukan nilai validitas yang dimofikasi dari penelitian). Dan Kelima, memberikan penilaian validitas yang modifikasi dari (Puspita et al., 2017).

\section{HASIL DAN PEMBAHASAN}

\section{Hasil}

Pengembangan booklet pada materi kingdom animalia dilaksanakan dengan menggunakan tiga tahapan dari model pengembangan 4D yang terdiri dari tahap pendefinisian (define), tahap perancangan 
(design), dan tahap pengembangan (develop). Hasil dari ketiga tahapan adalah sebagai berikut, Tahap Define, tahapan yang dilaksanakan pada tahap define adalah analisis kurikulum, analisis media, analisis peserta didik, analisis konsep dan analisis perumusan tujuan pembelajaran. Tahapan pendefinisian (define) ini dilaksanakan dengan penyebaran angket observasi kepada guru dan peserta didik di SMAS Pertiwi 2 Padang. Diketahui bahwa kriteria sumber belajar yang diinginkan peserta didik dapat dilihat pada Tabel 2. Kriteria sumber belajar ini dapat dijadikan acuan dan solusi untuk pengembangan booklet sebagai suplemen bahan ajar peserta didik yang menarik dan sekaligus praktis serta dilengkapi dengan beragam informasi tambahan. Booklet belum pernah dicobakan sebagai suplemen bahan ajar di SMA Pertiwi 2 Padang, khususnya pada materi kingdom animalia.

Tabel 2. Kriteria sumber belajar yang diinginkan peserta didik

\begin{tabular}{clc}
\hline No & \multicolumn{1}{c}{ Kriteria sumber belajar yang diinginkan peserta didik } & Jumlah (\%) \\
\hline 1 & Bacaan disertai gambar & $23 \%$ \\
2 & Berwarna pada setiap halaman & $32 \%$ \\
3 & Menggunakan bahasa yang mudah dipahami & $54 \%$ \\
4 & Materi yang disampaikan singkat, padat, dan jelas & $73 \%$ \\
5 & Berukuran lebih kecil dan praktis & $4 \%$ \\
6 & Ada tambahan informasi luar berkaitan dengan materi & $27 \%$ \\
7 & Terdapat penjelasan untuk istilah-istilah yang sulit & $36 \%$ \\
\hline
\end{tabular}

Tahap Design, Tahapan yang dilaksanakan pada tahap design adalah perancangan booklet sebagai suplemen bahan ajar pada materi kingdom animalia. Booklet ini mengandung beberapa komponen pelengkap yang terdiri atas cover, kata pengantar, Kompetensi Dasar, Indikator Pencapaian Kompetensi, Daftar isi, Mindmap, Materi, Info Biologi, Glosarium, Referensi, dan Biografi penulis. Aplikasi yang digunakan untuk merancang booklet adalah Microsoft Publisher 2010. Tampilan produk booklet pada materi Kingdom Animalia disajikan pada Gambar 1.

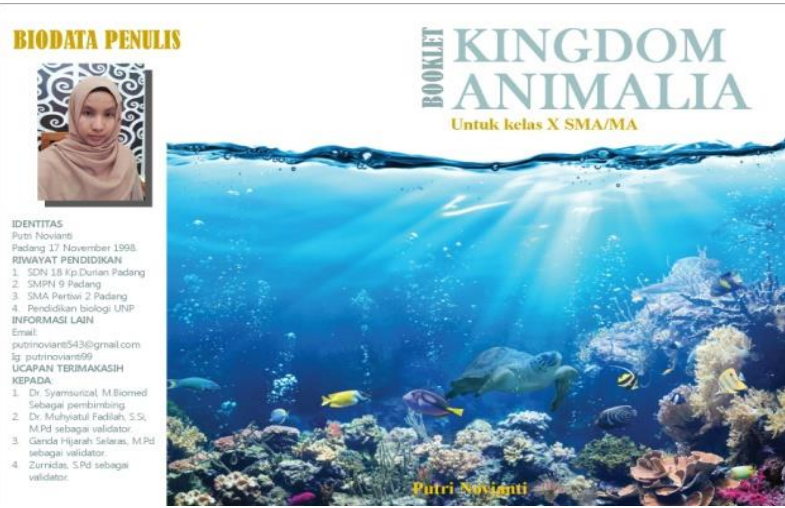

Cover Depan dan Belakang yang Terdapat Biografi Penulis

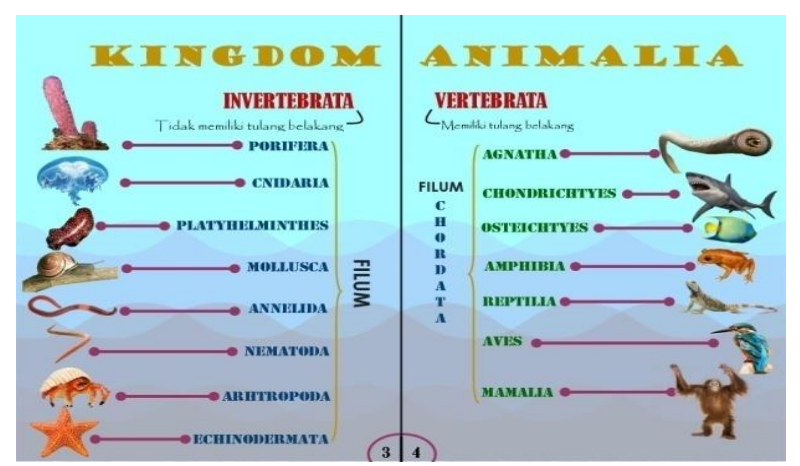

Tampilan Mindmap

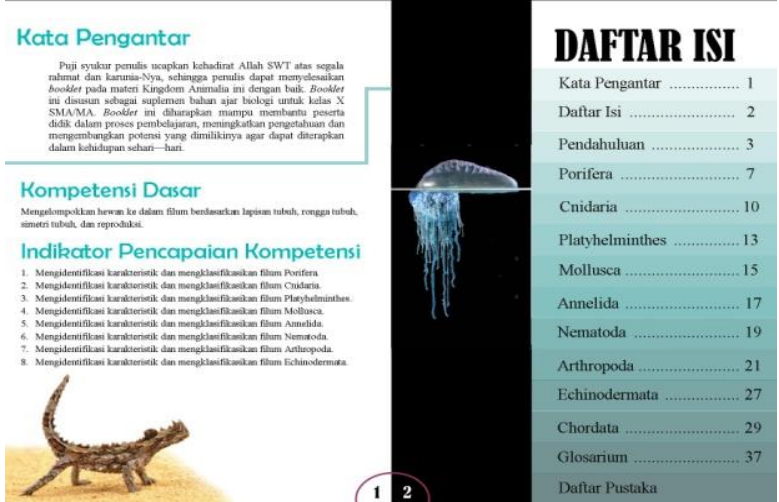

Tampilan Kata Pengantar, Kompetensi dan Daftar Isi

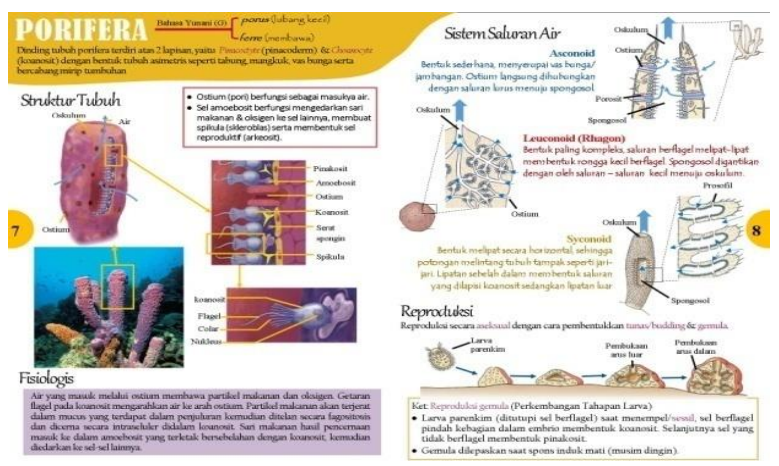

Tampilan Materi 


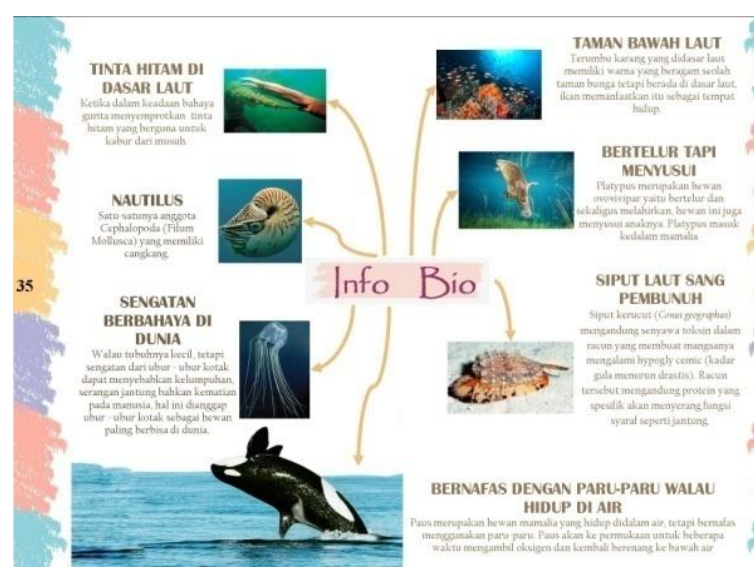

Tampilan Info Bio

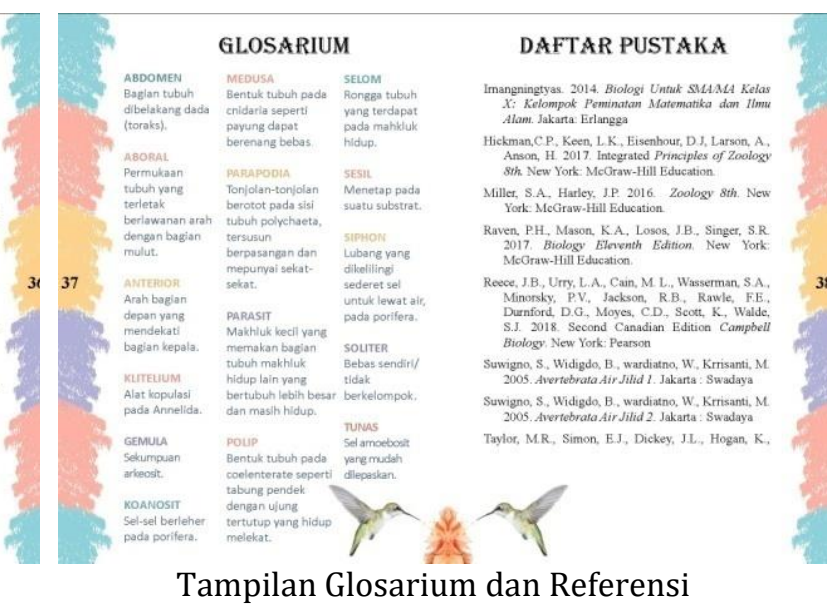

Tampilan Glosarium dan Referensi

Gambar 1. Tampilan produk booklet pada materi Kingdom Animalia

Tahap Develop, tahapan yang dilaksanakan pada tahap develop adalah validasi produk booklet. Proses validasi produk dilakukan oleh dua orang dosen biologi dan satu orang guru biologi SMA. Aspek penilaian validasi didasarkan pada aspek kelayakan isi, kebahasaan, penyajian, dan kegrafikan. Hasil validasi booklet sebagai suplemen bahan ajar pada materi Kingdom Animalia disajikan pada Tabel 3.

Tabel 3. Hasil Analisis Validasi Booklet sebagai suplemen bahan ajar pada materi kingdom animalia SMA/MA

\begin{tabular}{llll}
\hline No & Aspek & Nilai Validitas (\%) & Kategori \\
\hline 1 & Kelayakan isi & $94.80 \%$ & Sangat Valid \\
2 & Penyajian & $100 \%$ & Sangat Valid \\
3 & Kebahasaan & $95.83 \%$ & Sangat Valid \\
4 & Kegrafikan & $100 \%$ & Sangat Valid \\
\hline & Rata-rata & $\mathbf{9 7 . 6 6 \%}$ & Sangat Valid \\
\hline
\end{tabular}

\section{Pembahasan}

Booklet pada materi Kingdom Animalia dinyatakan dengan nilai 94,80\% dengan kategori sangat valid dari segi kelayakan isi karena booklet yang dikembangkan sudah memuat materi yang dapat menambah wawasan peserta. Bahan ajar yang baik harus memiliki materi yang jelas dan benar serta dapat menambah wawasan pesera didik (Probowati et al., 2020; Safruddin, 2020). Booklet pada materi Kingdom Animalia dinyatakan sangat valid dari segi penyajian karena booklet yang dikembangkan memuat kompetensi yang akan dicapai peserta didik. Media pembelajaran memiliki konsep materi yang disesuaikan dengan kompetensi yang ingin dicapai (Astuti et al., 2020; Kinanti \& Sudirman, 2018). Media yang digunakan layak dikembangkan jika didasarkan pada kompetensi (Dirman et al., 2014). Booklet pada materi Kingdom Animalia dinyatakan sangat valid dari segi kebahasaa karena booklet yang dikembangkan dengan penggunaan bahasa yang singkat, jelas, dan mudah dipahami peserta didik serta menambahkan glosarium untuk mengartikan kosakata penting yang terdapat pada materi. Kalimat yang sederhana, penggunaan tanda baca yang tepat dan kalimat tidak memiliki makna ganda lebih memudahkan peserta didik dalam memahami materi (Reni Anggraeni, 2018; Sepriadi et al., 2018). Booklet pada materi Kingdom Animalia dinyatakan sangat valid dalam aspek kegrafikan karena booklet yang dikembangkan dengan grafis dengan warna beragam yang menarik dan memiliki gambar yang jelas sehingga dapat menyampaikan materi kepada peserta didik secara efektif (Intika, 2018; Pralisaputri et al., 2016; Sapkota et al., 2020). Pendapat (Fitri \& Yogica, 2018) menyatakan bahwa media dinyatakan valid jika dapat mengefisiensikan waktu belajar peserta didik. Berdasarkan hasil analisis validasi keseluruh aspek penilaian booklet sebagai suplemen bahan ajar pada materi Kingdom Animalia SMA/MA mendapatkan nilai validitas $97,25 \%$ yang dinyatakan sangat valid. Pengembangan booklet pada materi Kingdom Animalia sudah dapat dijadikan media pembelajaran tambahan selain buku paket dan LKPD bagi peserta didik dalam proses pembelajaran. Bahan ajar layak digunakan jika sudah memenuhi pedoman dasar penyusunan bahan ajar (Arwita et al., 2020; Putro et al., 2016). Booklet pada materi Kingdom Animalia dapat dinyatakan sangat valid dan dapat dijadikan media pembelajaran. 


\section{SIMPULAN}

Booklet sebagai suplemen bahan ajar pada materi Kingdom Animalia kelas X SMA/MA dengan kriteria nilai sangat valid dan dapat dilakukan tahap selanjutnya, melakukan uji coba kepada peserta didik untuk melihat kepraktisan booklet ini. Pengembangan media ini diharapkan nantinya dapat dijadikan suplemen pelengkap media pembelajaran yang sudah ada di sekolah, khususnya pada materi Kingdom Animalia dan memudahkan peserta didik memahami materi Kingdom Animalia secara mandiri.

\section{DAFTAR RUJUKAN}

Adiko, H. S. S. (2019). Penggunaan Media Pembelajaran Berbasis Ict (Information Communications Technologies) dalam Meningkatkan Motivasi Belajar Peserta Didik. Akademika: Jurnal Ilmiah Media Publikasi Ilmu Pengetahuan Dan Teknologi. https://doi.org/10.31314/akademika.v7i2.312.

Aini, C. N., \& Habibi, M. W. (2020). Development of Booklet Based Science Learning Media for Junior High School. INSECTA: Integrative Science Education and Teaching Activity Journal. https://doi.org/10.21154/insecta.v1i2.2269.

Arwita, W., Simatupang, Z., \& Oktavianingsih, O. (2020). Pembelajaran Mandiri Menggunakan Modul Berbasis 6 Tugas untuk Mahasiswa Calon Guru Biologi pada Mata Kuliah Strategi Belajar Mengajar. Jurnal Pelita Pendidikan. https://doi.org/10.24114/jpp.v7i4.16749.

Astuti, D., Supriyanto, E., \& Muthoifin, M. (2020). Model Penjaminan Mutu Ketercapaian Kompetensi Dasar dalam Sistem Pembelajaran Online Pada Situasi Work From Home (WFH). Profetika: Jurnal Studi Islam. https://doi.org/10.23917/profetika.v21i1.11655.

Dirman, Nufus, H., \& Juarsih, C. (2014). Kegiatan Pembelajaran yang Mendidik : Dalam rangka Implementasi Standar Proses Pendidikan Siswa. Rineka Cipta.

Fitri, R., \& Yogica, R. (2018). Validitas Game Edukasi Kasifikasi Tumbuhan Berbasis Permainan Koa sebagai Media Pembelajaran Biologi. Jurnal Pedagogi Hayati, 2(1), 25-30.

Intika, T. (2018). Pengembangan Media Booklet Science For Kids sebagai Sumber Belajar di Sekolah Dasar. JRPD (Jurnal Riset Pendidikan Dasar). https://doi.org/10.26618/jrpd.v1i1.1234.

Kinanti, L. P., \& Sudirman, S. (2018). Analisis Kelayakan Isi Materi dari Komponen Materi Pendukung Pembelajaran dalam Buku Teks Mata Pelajaran Sosiologi Kelas Xi Sma Negeri Di Kota Bandung. SosietaS. https://doi.org/10.17509/sosietas.v7i1.10347.

Nisa, K., Ajizah, A., \& Amintarti, S. (2021). The Validity of Learning Media in the Form of Booklet Types of Pteridophyta (Fern) in the Riverbanks of Wisata Alam Sungai Kembang for Senior High School Grade X. BIO-INOVED: Jurnal Biologi-Inovasi Pendidikan. https://doi.org/10.20527/bino.v3i2.9978.

Pralisaputri, K. R., Soegiyanto, H., \& Muryani, C. (2016). Pengembangan Media Booklet Berbasis Sets pada Materi Pokok Mitigasi dan Adaptasi Bencana Alam Untuk Kelas X SMA. Jurnal GoEco.

Probowati, A., Gofur, A., \& Lukiati, B. (2020). Analisis Kebutuhan untuk Pengembangan Bahan Ajar Fisiologi Hewan dan Manusia pada Jurusan Biologi. Jurnal Pendidikan: Teori, Penelitian, Dan Pengembangan. https://doi.org/10.17977/jptpp.v5i6.13586.

Puspita, A., Kurniawan, A. D., \& Rahayu, H. M. (2017). Pengembangan Media Pembelajaran Booklet pada Materi Sistem Imun terhadap Hasil Belajar Siswa Kelas Xi Sman 8 Pontianak. Jurnal Bioeducation. https://doi.org/10.29406/524.

Putra, A., \& Milenia, I. F. (2021). Systematic Literature Review: Media Komik dalam Pembelajaran Matematika. MATHEMA: Jurnal Pendidikan Matematika. https://doi.org/10.33365/jm.v3i1.951.

Putro, S. D. K., Umie Lestari, D., \& Lukiat, B. (2016). Pengembangan Buku Ajar Perkembangan Hewan Berbasis Penelitian Metamorfosis Ulat Sutera Bombyx Mori L. Jurnal Pendidikan Teori, Penelitian Dan Pengembangan.

Rahmatih, A. N., Yuniastuti, A., \& Susanti, R. (2017). Pengembangan Booklet Berdasarkan Kajian Potensi dan Masalah Lokal sebagai Suplemen Bahan Ajar SMK Pertanian. Journal of Innovative Science Education.

Rejeki, R., Adnan, M. F., \& Siregar, P. S. (2020). Pemanfaatan Media Pembelajaran pada Pembelajaran Tematik Terpadu di Sekolah Dasar. Jurnal Basicedu. https://doi.org/10.31004/basicedu.v4i2.351.

Reni Anggraeni, A. Y. L. S. (2018). Keterbacaan Buku Ajar Bahasa Indonesia di Sekolah Menengah Pertama (Text Book Readability of Indonesian Language in Junior High School). Jurnal Bahasa, Sastra Dan Pembelajarannya. https://doi.org/10.20527/jbsp.v7i2.4428.

Rosyidah, N., Hidayat, J. N., \& Azizah, L. F. (2019). Uji Kelayakan Media Uriscrap (Uri Scrapbook) Menggunakan Model Pengembangan 4d. LENSA (Lentera Sains): Jurnal Pendidikan IPA. https://doi.org/10.24929/lensa.v1i1.43.

Safruddin, S. (2020). Pengembangan Bahan Ajar Pendidikan IPS Berbasis Kearifan Lokal Maja Labo Dahu 
untuk Pembentukan Karakter Siswa SMP Kabupaten Bima. JISIP (Jurnal Ilmu Sosial Dan Pendidikan). https://doi.org/10.36312/jisip.v4i3.1188.

Sapkota, D., Baird, K., Saito, A., Budhathoki, S. S., Pokharel, R., Basnet, S., \& Anderson, D. (2020). Development and Validation of an Information Booklet Aimed at Promoting Mental Health for Pregnant Women with a History of Abuse. Journal of Nepal Health Research Council. https://doi.org/10.33314/jnhrc.v17i4.2017.

Sari, L. A. (2019). Efektivitas Media Booklet dan Leaflet Terhadap Pengetahuan Remaja Putri Tentang Dampak Kehamilan Remaja. Jambura Journal of Health Sciences and Research. https://doi.org/10.35971/jjhsr.v1i2.2388.

Sepriadi, I., Sumarmin, R., \& Fitri, R. (2018). Development of Animal Comic Media (Anicom) Oriented with Contextual Approach for Grade $\mathrm{X}$ Students. Bioeducation Journal. https: //doi.org/10.24036/bioedu.v2i2.103.

Sya'bania, N., Anwar, M., \& Wijaya, M. (2020). Pengembangan Media Pembelajaran Berbasis Video Animasi dengan Model Pembelajaran Inkuiri Terbimbing untuk Meningkatkan Motivasi dan Hasil Belajar Peserta Didik. Journal of Chemical Information and Modeling.

Yudistira, O. K., Syamsurizal, S., Helendra, H., \& Attifah, Y. (2021). Analisis Kebutuhan Pengembangan Booklet Sistem Imun Manusia sebagai Suplemen Bahan Ajar Biologi Kelas XI SMA. Journal for Lesson and Learning Studies. https://doi.org/10.23887/jlls.v4i1.34289.

Yusuf, M., Saraswati, U., \& Ahmad, T. A. (2019). Pengembangan Bahan Ajar Perang Lasem Dalam Bentuk Booklet Untuk Pembelajaran Sejarah Lokal di SMA Negeri 1 Lasem. Indonesian Journal of History Education. https://doi.org/10.15294/ijhe.v7i1.32287. 